\title{
Introduction: Access to Life-Saving Medicines and Intellectual Property Rights
}

\author{
DORIS SCHROEDER
}

Health is a fundamental human right recognized in at least 135 national constitutions.... Access to essential medicines is a prerequisite for realizing that right. $^{1}$

As the authors of the Millennium Development Goals (MDG) Gap Task Force have noted, access to medicines is a vital component of realizing the human right to health. Without reliable access to drugs, the highest attainable standard of health cannot be achieved.

Intense debates about access to drugs are led around the globe. In affluent countries, discussions often focus on whether highly expensive interventions should be made available through national health systems. For instance, in 2008, the kidney cancer drug Sutent was not available to patients on the National Health Service in Britain, ${ }^{2}$ a decision that was reversed after "a public outcry" in which "patients said they were being condemned to an early death."3

In developing countries, the situation is much graver, as rationing and shortages of drugs pertain not only to highly expensive interventions. For instance, in 2008, 1.3 million people died from tuberculosis, a disease that is-in most cases-easily curable through low-cost antibiotics. ${ }^{4}$

Nearly $30 \%$ of the world population do not have access to life-saving medicines at all, as Anand Grover, the UN Special Rapporteur on the right of everyone to the enjoyment of the highest attainable standard of physical and mental health, noted in a recent report: ${ }^{5}$

\begin{abstract}
Nearly 2 billion people lack access to essential medicines. Improving access to medicines could save 10 million lives a year, 4 million in Africa and South East Asia. The inability of populations to access medicines is partly due to high costs.... TRIPS [Trade-Related Aspects of Intellectual Property Rights Agreement] and FTAs [Free Trade Agreements] have had an adverse impact on prices and availability of medicines, making it difficult for countries to comply with their obligations to respect, protect, and fulfill the right to health.
\end{abstract}

The reasons for lack of access to life-saving medicines are manifold. High prices generated through intellectual property rights (IPRs) are only one of many factors, as the above tuberculosis example indicates. This symposium focuses on two of the problems the poor face in relation to access to drugs.

First, because of monopoly pricing powers granted to innovators, the poor cannot afford those medicines that are still under patent protection. One can speak of an access problem here: medicines are priced beyond the reach of the poor.

Second, because pharmaceutical innovation is primarily steered through the market system, diseases that are largely confined to the poor are rarely investigated. 
Neglected or orphan diseases often rely on philanthropic endeavors to be the target for drug research. This second problem could be termed an availability problem, that is, drugs are not being developed for the needs of the poor. ${ }^{6}$

In the first part of this symposium, Peter Singer and Doris Schroeder examine how the right to IPR protection relates to the right to health, arguing that the latter takes precedence both within international law and natural rights philosophy and on grounds of social utility. In the second part, Tikki Pang describes the contribution of the World Health Organization (WHO) toward resolving the availability problem of drugs. In the third part, Doris Schroeder asks whether the pharmaceutical sector has a coresponsibility for resolving the access problem, focusing on nonsupererogatory duties. In the fourth part, Klaus Leisinger and Karin Schmitt provide an enlightened industry viewpoint of the role of the pharmaceutical sector in resolving the access problem. In the fifth part, Jack Beetson reminds pharmaceutical collaborators of the essentials when working with indigenous communities to bring traditional medicines to market. And, finally, Thomas Pogge and Aidan Hollis close the symposium with a reflective epilogue.

\section{Notes}

1. United Nations MDG Gap Task Force. Delivering on the Global Partnership for Achieving the Millennium Development Goals, 2008; available at http://www.who.int/medicines/mdg/ MDG8EnglishWeb.pdf, page 42 (last accessed 31 Jul 2010).

2. Templeton SK. Banned cancer drugs better than NHS ones. The Sunday Times; available at http:// www.timesonline.co.uk/tol/life_and_style/health/article4138237.ece (last accessed 31 Jul 2010).

3. Smith R. Sutent for kidney cancer approved on NHS but other drugs turned down. Telegraph; available at http://www.telegraph.co.uk/health/healthnews/6087834/Sutent-for-kidney-cancerapproved-on-NHS-but-other-drugs-turned-down.html (last accessed 31 Jul 2010).

4. World Health Organization. Tuberculosis; available at http://www.who.int/mediacentre/ factsheets/fs104/en/ (last accessed 31 Jul 2010).

5. Grover A. Promotion and Protection of all Human Rights, Civil, Political, Economic, Social and Cultural Rights, including the Right to Development, a Report of the Special Rapporteur on the Right of Everyone to the Enjoyment of the Highest Attainable Standard of Physical and Mental Health, 2009, United Nations, A/HRC/11/12, p.6, 7, 28, available at http://www2.ohchr.org/english/bodies/hrcouncil/docs/ 11session/A.HRC.11.12_en.pdf (last accessed 31 Jul 2010).

6. Selgelid M, Sepers EM. Patents, profits, and the price of pills: Implications for access and availability. In: Illingworth P, Schuklenk U, Cohen JC, eds. The Power of Pills: Social, Ethical and Legal Issues in Drug Development, Marketing and Pricing Policies. London: Pluto Press; 2006:153-63. 


\section{University Library}

\section{- M M N E R VA A gateway to Melbourne's research publications}

Minerva Access is the Institutional Repository of The University of Melbourne

Author/s:

Schroeder, D

Title:

Introduction: Access to Life-Saving Medicines and Intellectual Property Rights

Date:

2011-04-01

Citation:

Schroeder, D. (2011). Introduction: Access to Life-Saving Medicines and Intellectual Property Rights. CAMBRIDGE QUARTERLY OF HEALTHCARE ETHICS, 20 (2), pp.277-278. https://doi.org/10.1017/S0963180110000927.

Publication Status:

Published

Persistent Link:

http://hdl.handle.net/11343/33018 